\title{
Methylation of the SEPT9_v2 promoter as a novel marker for the detection of circulating tumor DNA in breast cancer patients
}

\author{
SAKI MATSUI, NAOFUMI KAGARA, CHIEKO MISHIMA, YASUTO NAOI, MASAFUMI SHIMODA, \\ ATSUSHI SHIMOMURA, KENZO SHIMAZU, SEUNG JIN KIM and SHINZABURO NOGUCHI
}

Department of Breast and Endocrine Surgery, Osaka University Graduate School of Medicine, Osaka 565-0871, Japan

Received December 15, 2015; Accepted July 25, 2016

DOI: $10.3892 / o r .2016 .5004$

\begin{abstract}
The aim of the present study was to evaluate the promoter methylation status of SEPT9_v2 in breast cancer and to detect this methylated gene in circulating tumor DNA (ctDNA) in plasma. Bisulfite sequencing was performed with a next generation sequencer. Methylation of the SEPT9_v2 promoter was found in $67 \%(8 / 12)$ of breast cancer cell lines and $53 \%(10 / 19)$ of breast tumor tissue, but not in normal breast tissue (0/19). A clear inverse correlation was observed between the expression of SEPT9_v2 mRNA and the methylation index (MI) both in cell lines and breast cancer tissues. The MI of SEPT9_v2 was significantly higher in non-basal subtype of breast cancer $(13.0 \%, \mathrm{n}=84)$ than in basal subtype $(3.0 \%, \mathrm{n}=23)(\mathrm{P}<0.0001)$. Methylated SEPT9_v2 ctDNA in plasma was detected in $11 \%(9 / 82)$ of primary breast cancer patients and $52 \%(26 / 50)$ of metastatic breast cancer patients, but not in the healthy controls $(0 / 51)$. These results indicate that SEPT9_v2 promoter hypermethylation, which silences the expression of SEPT9_v2 mRNA, is observed in a significant proportion of breast tumors, and that methylated SEPT9_v2 may serve as a novel tumor marker for breast cancer.
\end{abstract}

\section{Introduction}

Methylation of tumor suppressor gene promoters, one of the most common events in various types of cancers, is generally tumor-specific $(1,2)$. Methylation of circulating tumor DNA (ctDNA) can be detected in the plasma or serum of breast cancer patients (3-9); thus, methylated ctDNA is a promising cancer biomarker (2). Several genes including $G S T P 1, R A S S F 1 A$ and $R A R \beta 2$ are methylated in breast tumor tissue $(3,10,11)$, and the methylation of these genes can be detected in ctDNA of breast cancer patients $(3,4,6)$. Although

Correspondence to: Dr Naofumi Kagara, Department of Breast and Endocrine Surgery, Osaka University Graduate School of Medicine, 2-2-E10 Yamadaoka, Suita-shi, Osaka 565-0871, Japan E-mail: kagaran@onsurg.med.osaka-u.ac.jp

Key words: biomarker, breast cancer, methylation, next generation sequencing, SEPT9 several studies have investigated the clinical application of these methylated ctDNAs as prognostic indicators $(4,5)$ or monitoring markers of systemic therapy $(7,8)$, a more sensitive and specific methylated ctDNA marker is needed.

SEPT9 belongs to a family of GTP-binding proteins recognized as components of the cytoskeleton. These proteins are involved in several cellular processes including membrane trafficking, cytokinesis, angiogenesis, and cell proliferation $(12,13)$. SEPT9 consists of at least seven transcripts with diverse functions $(13,14)$. Some of these transcripts possess tumor suppressor functions, while others have oncogenic properties (15-18). SEPT9_v2 has been shown to be epigenetically modified in colorectal cancer, and an assay for detecting methylated SEPT9_v2 ctDNA in plasma has been developed and validated for clinical use as a marker for the early detection of colorectal cancer (19-21). Recently, a more sensitive and specific (48 and 92\%, respectively) assay for methylated SEPT9_v2 has been developed for colorectal cancer screening (22). SEPT9 methylation can be also detected in other types of cancers, including breast cancer (23), suggesting that the assay for methylated SEPT9_v2 in plasma may be useful in breast cancer patients.

The aim of the present study was to determine whether methylation of the SEPT9_v2 promoter was associated with the expression of this gene in breast cancer cells. In addition, we sought to clarify the clinicopathological characteristics of breast tumors containing methylated SEPT9_v2. We analyzed the methylation of the SEPT9_v2 promoter using next generation sequencing (NGS), which provides a quantitative methylation index (MI) within a broad CpG area. Lastly, we examined whether methylated SEPT9_v2 ctDNA can be detected in the plasma of breast cancer patients, and explored its utility as a novel blood biomarker for breast cancer diagnosis.

\section{Materials and methods}

Patients and breast tumor samples

Study I. Nineteen pairs of tumor and normal tissues were obtained at surgery between 2001 and 2004 from primary breast cancer (PBC) patients who received no preoperative chemotherapy or hormonal therapy. The clinicopathological characteristics of these patients are summarized in Table I. Normal tissue samples were obtained from the quadrant not 
harboring cancer. Tissue samples were snap-frozen in liquid nitrogen and kept at $-80^{\circ} \mathrm{C}$ until use.

Study II. Tumor samples from stage II or III PBC patients $(n=107)$ were retrospectively included in the present study. These patients had been treated at Osaka University Hospital between 2004 and 2009 with neoadjuvant chemotherapy (NAC) consisting of paclitaxel $\left(80 \mathrm{mg} / \mathrm{m}^{2}\right)$ weekly for 12 cycles followed by 5 -fluorouracil $\left(500 \mathrm{mg} / \mathrm{m}^{2}\right)$, epirubicin $\left(75 \mathrm{mg} / \mathrm{m}^{2}\right)$ and cyclophosphamide $\left(500 \mathrm{mg} / \mathrm{m}^{2}\right)$ every three weeks for four cycles. Each patient underwent vacuum-assisted biopsy of the tumors, and tumor samples were snap-frozen in liquid nitrogen and kept at $-80^{\circ} \mathrm{C}$ until use. Histological grade, estrogen receptor (ER), progesterone receptor (PR) and HER2 status were determined as previously described (11). Ki67 was defined as 'high' when $\geq 20 \%$ of tumor cells was immunohistochemically positive (clone; MIB-1). A pathological complete response (pCR) was defined as no evidence of invasive cancer components in the breast irrespective of axilla lymph node metastases. Intrinsic subtypes were determined by DNA microarray using the PAM50 method $(24,25)$. The clinicopathological characteristics of these patients are summarized in Table II.

Study III. For the measurement of methylated SEPT9_v2 ctDNA in plasma, $2 \mathrm{ml}$ plasma samples were obtained from healthy controls $(n=51)$, stage II or III PBC patients $(n=82)$ and metastatic breast cancer $(\mathrm{MBC})$ patients $(\mathrm{n}=50)$ at Osaka University Hospital and Osaka Police Hospital between 2012 and 2014. Among these patients, frozen tumor tissues or formalin-fixed paraffin-embedded (FFPE) tumor tissues were available from $49 \mathrm{PBC}$ and $25 \mathrm{MBC}$ patients. These tumor tissues were subjected to the SEPT9_v2 methylation assay. These studies were approved by the Institutional Review Board for Clinical Research, Osaka University Graduate School of Medicine and the Osaka Police Hospital Ethical Committee. Informed consent was obtained from each patient before sampling.

DNA extraction and sodium bisulfite treatment. Total DNA from cell lines was isolated using TRIzol ${ }^{\circledR}$ reagent (Invitrogen, Carlsbad, CA, USA) and total DNA from snap-frozen breast tissue was extracted using the DNeasy ${ }^{\circledR}$ Blood and Tissue kit (Qiagen, Valencia, CA, USA). For DNA extraction from FFPE tumor tissues, three to five $10-\mu \mathrm{m}$ sections/tumor were cut from the FFPE tumor tissues, and the tumor area was dissected with a scalpel under a stereoscopic assistance. Total DNA from the paraffin sections was extracted using the QIAamp DNA FFPE kit (Qiagen). For the laser captured microdissection (LCM), a $10 \mu \mathrm{m}$ section of the FFPE tumor tissues was mounted onto a polyethylene napthalate membrane slide (Leica Microsystems $\mathrm{GmbH}$, Wetzlar, Germany), and the epithelium or stroma was separately collected with the laser microdissection system LMD7000 (Leica) (26) and DNA was extracted using the QIAamp DNA Micro kit (Qiagen). One microgram of genomic DNA was subjected to sodium bisulfite treatment with the EpiTect ${ }^{\circledR}$ Bisulfite kit (Qiagen). Plasma DNA was extracted using the QIAamp ${ }^{\circledR}$ Circulating Nucleic Acid kit (Qiagen) from a $2 \mathrm{ml}$ plasma sample and subjected to sodium bisulfite treatment as previously described (4).
Table I. Clinicopathological characteristics of breast tumors (study I).

\begin{tabular}{|c|c|c|}
\hline Characteristics & No. of patients & $\%$ \\
\hline All cases & 19 & \\
\hline \multicolumn{3}{|l|}{ Age (years) } \\
\hline$<50$ & 9 & 52.6 \\
\hline$\geq 50$ & 10 & 47.4 \\
\hline \multicolumn{3}{|l|}{ Menopausal status } \\
\hline Pre & 10 & 52.6 \\
\hline Post & 9 & 47.4 \\
\hline \multicolumn{3}{|l|}{ Tumor size (cm) } \\
\hline$<2$ & 5 & 26.3 \\
\hline$\geq 2$ & 14 & 73.7 \\
\hline \multicolumn{3}{|c|}{ Lymph node metastasis } \\
\hline Negative & 13 & 68.4 \\
\hline Positive & 6 & 31.6 \\
\hline \multicolumn{3}{|l|}{ Histological type } \\
\hline IDC & 18 & 94.7 \\
\hline Special type & 1 & 5.26 \\
\hline \multicolumn{3}{|l|}{ Histological grade } \\
\hline 1,2 & 13 & 68.4 \\
\hline 3 & 6 & 31.6 \\
\hline \multicolumn{3}{|l|}{ ER } \\
\hline Negative & 7 & 36.8 \\
\hline Positive & 12 & 63.2 \\
\hline \multicolumn{3}{|l|}{ PR } \\
\hline Negative & 10 & 52.6 \\
\hline Positive & 9 & 47.4 \\
\hline \multicolumn{3}{|l|}{ HER2 } \\
\hline Negative & 12 & 63.2 \\
\hline Positive & 7 & 36.8 \\
\hline \multicolumn{3}{|l|}{ Ki67 } \\
\hline Low & 5 & 26.3 \\
\hline High & 1 & 5.26 \\
\hline Unknown & 13 & 68.4 \\
\hline \multicolumn{3}{|l|}{ Subtype (IHC) $)^{\mathrm{a}}$} \\
\hline Luminal A & 9 & 47.4 \\
\hline Luminal B & 3 & 15.8 \\
\hline HER2 & 4 & 21.1 \\
\hline Triple negative & 3 & 15.8 \\
\hline
\end{tabular}

IDC, invasive ductal carcinoma; IHC immunohistochemistry; ${ }^{a} \mathrm{lu}-$ minal A, ER and/or PR-positive and HER2-negative; luminal B, ER and/or PR-positive and HER2-positive; HER2, ER and PR-negative and HER2-positive; triple negative, ER, PR and HER2-negative; ER, estrogen receptor; $\mathrm{PR}$, progesterone receptor.

Quantitative SEPT9_v2 promoter methylation analysis using NGS and methylation-specific polymerase chain reaction. The NGS methylation assay was performed with the GS Junior system (Roche Diagnostics, Basel, Switzerland) according to the manufacturer's instructions. Data were 
Table II. Comparison of the SEPT9_v2 MI with clinicopathological parameters of breast tumors (study II).

\begin{tabular}{lcc}
\hline & & SEPT9_v2 \\
\cline { 3 - 3 } Characteristics & $\begin{array}{c}\text { No. of } \\
\text { pts. }\end{array}$ & MI \\
& (mean $\pm \mathrm{SD})$ & P-value \\
\hline
\end{tabular}

\begin{tabular}{lll}
\hline $\begin{array}{l}\text { All cases } \\
\text { Age (years) }\end{array}$ & 107 & \\
$<50$ & & \\
$\geq 50$ & 49 & $10.1 \pm 16.1$ \\
& 58 & $11.7 \pm 12.8$
\end{tabular}

Menopausal status

Pre

$51 \quad 11.5 \pm 15.9$

Post

56

$10.3 \pm 12.9$

T stage

$\mathrm{T} 1,2$

T3, 4

84

23

Lymph node metastasis

Negative

Positive

Stage

II

$10.2 \pm 12.5$

III

$13.9 \pm 21.2$

Histological type

IDC

Special type

ER

Negative

Positive

PR

$$
\text { Negative }
$$

Positive

HER2

Negative

Positive

Subtype (IHC) ${ }^{\mathrm{a}}$

Luminal A

Luminal B

HER2

Triple negative

Subtype (PAM50)

\section{Luminal A}

Luminal B

HER2

Basal-like

Normal-like

Histological grade

$$
\begin{aligned}
& 1,2 \\
& 3
\end{aligned}
$$

Ki67

Low

High

0.539
Table II. Continued.

\begin{tabular}{lccc}
\hline & & \multicolumn{2}{c}{ SEPT9_v2 } \\
\cline { 3 - 4 } Characteristics & No. of & MI & \\
\hline pts. & (mean \pm SD) & P-value \\
Pathological response & & & $<0.001$ \\
Non-pCR & 74 & $13.4 \pm 15.7$ & \\
pCR & 33 & $5.2 \pm 8.47$ & \\
\hline
\end{tabular}

MI, methylation index; pts., patients; IDC invasive ductal carcinoma; IHC immunohistochemistry; 'luminal A, ER and/or PR-positive and HER2-negative; luminal B, ER and/or PR-positive and HER2-positive; HER2, ER and PR-negative and HER2-positive;

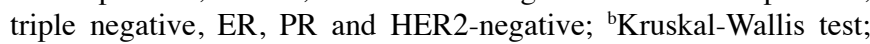
$\mathrm{ER}$, estrogen receptor; PR, progesterone receptor.

0.486 analyzed using GS Amplicon Variant Analyzer software ver. 2.7 (Roche Diagnostics). The MI was calculated by dividing the number of cytosines by the total reads at each CpG site. NGS primers used for SEPT9_v2 methylation of frozen tissue or cell lines were designed as follows: forward, 5'-ATTTAGTTGAGTTAGGGGGTTTAGG-3' and reverse, 5'-AACAAACACAAACAACAATAAAAAAAA-3' (NGS

0.123 primer long, Fig. 1). Among all $57 \mathrm{CpG}$ sites, the average MI of the 11 sites (47-57th CpGl; Fig. 1) showing the most significant difference between cancer and normal tissue was used for the statistical analysis of methylation. NGS primers used for DNA from FFPE specimens were designed as follows: forward, 5'-GGGGGATTTTGTTAGGGGTA-3' and reverse, 5'-AACAAACACAAACAACAATAAAAAAAA -3'

0.002 (NGS primer short, Fig. 1). The NGS short primer included seven $\mathrm{CpG}$ sites, equivalent to 51st-57th CpG (Fig. 1). The cut-off of $\mathrm{MI} \geq 10 \%$ was used to define the hypermethylation of SEPT9_v2 in the breast cancer cell lines and breast tumors according to the previous studies (27-30). For detecting the methylated SEPT9_v2 in plasma and in the epithelial or stromal cells obtained by LCM, a quantitative methylation-specific polymerase chain reaction (MSP) assay was performed with the protocol modified as previously described (20). The SEPT9_v2 oligonucleotide sequence including the 20-24th CpG sites (Fig. 1) for detection of methylated SEPT9_v2 ctDNA in plasma were designed as follows: forward, 5'-AAATAATCCCATCCAACTA-3' and reverse, 5'-GATT-dspacer-GTTGTTTATTAGTTATTATGT-3' (Fig. 1) (20). The rCpG sequence was used as a reference control as we previously reported (3). The SEPT9_v2 and $\mathrm{rCpG} \mathrm{PCR}$ reactions were performed using a $9 \mu \mathrm{l}$ aliquot of the bisulfite DNA eluate, in a $25 \mu \mathrm{l}$ total volume using 96-well plates. Methylated SEPT9_v2 ctDNA in plasma was defined as positive when quantification cycles were $<50$ for SEPT9_v2 and $<33.7$ for $\mathrm{rCpG}$ as the loading reference (22).

In situ hybridization for SEPT9_v2 $m R N A$. The 0.116 QuantiGene ${ }^{\circledR}$ ViewRNA In Situ Hybridization Tissue Assay kit (Affymetrix, Santa Clara, CA, USA) was used according to the manufacturer's protocol. FFPE sections $(4 \mu \mathrm{m})$ of tumor tissue were incubated for $20 \mathrm{~min}$ at $98^{\circ} \mathrm{C}$ with a pretreatment 
solution followed by protease digestion for $10 \mathrm{~min}$. The SEPT9_v2- or glyceraldehyde 3-phosphate dehydrogenase $(G A P D H)$-specific View RNA ${ }^{\text {TM }}$ Probe set (Affymetrix) was hybridized for $3 \mathrm{~h}$. This probe set was designed to hybridize the SEPT9_v2-specific sequence with a length of $342 \mathrm{bp}$, which comprises $25 \%$ of the length regularly required for in situ hybridization (ISH) (chromosome 17; 77,373,207 to $77,373,548$ ). ISH images were captured by a fluorescent microscope (BZ-9000; Keyence, Osaka, Japan). Signal intensity was semi-quantitatively determined based on the number of cytoplasmic fluorescent dots in five non-overlapping fields at high-power magnification (x400).

Isolation of breast tumor cells by magnetic-activated cell sorting. Breast tumor cells were isolated from the FFPE tumor tissue by magnetic-activated cell sorting (MACS) using the EasySep Human EpCAM Positive Selection Cocktail, the EasySep Human MUC1 Positive Selection Cocktail, and EasySep Magnetic Particles (Stem Cell Technologies, Vancouver, BC, Canada) as previously described (31). Total DNA was extracted from the isolated tumor cells using the QIAamp ${ }^{\circledR}$ DNA FFPE Tissue kit (Qiagen).

Demethylation study with 5-aza-2'-deoxycytidine in cell lines. Twelve breast cancer cell lines (MCF7,ZR75-1,T47D,ZR75-30, MDA-MB-361, BT474, SKBR3, AU565, MDA-MB-453, MDA-MB-231, MDA-MB-468 and BT-20) and one normal breast epithelial cell line (HMEC) were cultured according to ATCC culture guides. For demethylation studies, cultured cells were treated with $10 \mu \mathrm{mol} / 1$ 5-aza-2'-deoxycytidine (Sigma-Aldrich, St. Louis, MO, USA) or with dimethyl sulfoxide as control for $72 \mathrm{~h}$. The medium was changed every $24 \mathrm{~h}$.

$R N A$ extraction and quantitative real-time PCR. Total RNA was isolated from cell lines using TRIzol ${ }^{\circledR}$ reagent (Invitrogen). One microgram of total RNA was reversetranscribed for single stranded cDNA using random primers and the ReverTra Ace ${ }^{\circledR}$ qPCR RT kit (Toyobo, Osaka, Japan). The reverse-transcription reaction was performed at $65^{\circ} \mathrm{C}$ for $5 \mathrm{~min}$ and subsequently at $37^{\circ} \mathrm{C}$ for $15 \mathrm{~min}$ and $98^{\circ} \mathrm{C}$ for 5 min. mRNA was quantitated using the LightCycler 480 Real-Time PCR system (Roche Applied Science, Mannheim, Germany) at $95^{\circ} \mathrm{C}(10 \mathrm{~min})$, followed by 50 cycles of $95^{\circ} \mathrm{C}$ $(15 \mathrm{sec}), 60^{\circ} \mathrm{C}(60 \mathrm{sec})$ and $1 \mathrm{cycle}$ of $50^{\circ} \mathrm{C}(10 \mathrm{sec}) . S E P T 9 \_v 2$ and $G A P D H$ TaqMan ${ }^{\circledR}$ Gene Expression Assays (assay identification nos. are Hs01107941_m1 and Hs02758991_g1, respectively; Applied Biosystems, Foster City, CA, USA) were used for quantitative real-time PCR. The expression of SEPT9 $v 2$ was normalized to that of $G A P D H$, and each assay was performed in duplicate. Each 5-aza-2'-deoxycytidine-treated breast cancer cell line was normalized to its control, which was set to a value of 1 .

Statistical analyses. JMP statistical software (version 10; SAS Institute, Cary, NC, USA) was used for statistical analyses. Associations between the various parameters and the SEPT9_v2 MI were evaluated using Student's t-test for two groups or the Kruskal-Wallis test for more than two groups. The paired t-test was used for comparison of frozen cancer and normal tissue MIs in matched-pair samples. Dunnett's test was used for comparison of SEPT9_v2 MIs in each of the subtypes. Univariate and multivariate analyses of various parameters for their association with pCR were conducted using the logistic regression model. All statistical analyses were two-sided and P-values $<0.05$ were considered statistically significant.

\section{Results}

Methylation of the SEPT9_v2 promoter and its impact on gene expression in breast cancer cell lines. The NGS methylation assay was performed on the SEPT9_v2 promoter in 12 breast cancer cell lines and a normal human mammary epithelial cell line. A representative NGS result is shown in Fig. 2. The SEPT9_v2 gene promoter was hypermethylated in eight and hypomethylated in four breast cancer cell lines and normal human mammary epithelial cells (Fig. 3A).

The expression of SEPT9_v2 mRNA was examined by quantitative real-time PCR using SEPT9_v2-specific primers and probes. There was an inverse correlation between the expression of SEPT9_v2 mRNA and the MI (Pearson's correlation coefficient $=-0.987$ ) (Fig. 3A). We then treated eight of these cell lines with a demethylating agent $(10 \mu \mathrm{M} 5$-aza-2'-deoxycytidine) and compared mRNA expression between treated and untreated cells. Treatment with 5-aza-2'-deoxycytidine induced 20- to 110-fold upregulation of mRNA expression in all four hypermethylated breast cancer cell lines (MCF7, T47D, AU565 and MDA-MB-231) (Fig. 3B). There was no upregulation in the four hypomethylated breast cancer cell lines (MDA-MB-361, BT474, SKBR3 and MDA-MB-468), demonstrating that the SEPT9_v2 gene was re-expressed by demethylation of its promoter region.

Methylation and expression of SEPT9_v2 in human breast cancer tissues. To study the methylation status of SEPT9_v2 in human breast cancer and normal breast tissues, the NGS methylation assay was performed using 19 paired tumor and normal tissues (study I). The MI was significantly higher in tumor than normal tissues (median values $=10.0$ and $1.7 \%$, respectively; $\mathrm{P}=0.003$ ) (Fig. 4A). The proportion of SEPT9_v2 tumors that were hypermethylated ( $\mathrm{MI} \geq 10 \%)$ was $53 \%$.

For more accurate assessment of the cancer cell-specific methylation status, we isolated cells from FFPE tumor tissue by the MACS method. The isolated tumor cells were subjected to the NGS methylation assay. Six tumor tissue samples with a relatively low-MI $(<30 \%)$ were analyzed since the low-MI was speculated to be due to contamination by normal stromal and inflammatory cells. The MI was clearly high in the tumor cells isolated from the three tumors with a relatively high-MI. However, the MI was low in tumor cells isolated from the remaining three tumors with a very low-MI (Fig. 4B).

Relationship between SEPT9_v2 methylation and clinicopathological characteristics. The NGS methylation assay of SEPT9_v2 was carried out using the vacuum-assisted biopsy specimens obtained before NAC (study II). The relationship between the extent of SEPT9_v2 methylation and various clinicopathological parameters including response to NAC was examined (Table II). SEPT9_v2 hypermethylation ( $\mathrm{MI} \geq 10 \%)$ was observed in $37 \%$ (40/107) of the specimens. Hypermethylation was significantly associated 


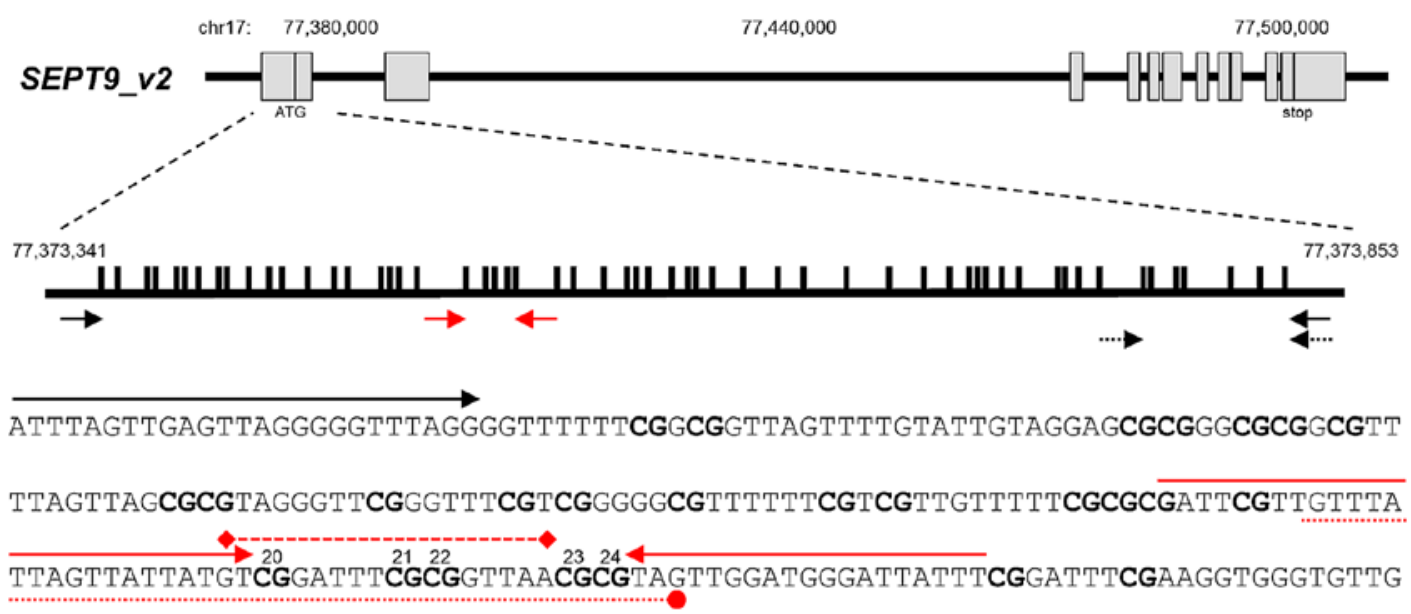

GGTTGGTTGTTGCGGTCGCGGACGTGTTGGAGAGGATTTTGCGGGTGGGTTTGGCGCGGGACGGGGGTGCGTTG

AGGGGAGACGGGAGTGCGTTGAGGGGAGACGGGATTTTTAATTTAGGCGTTTTTTCGTTGAGAGCGTCGCGCGT

TTTCGGTTTCGTGTTCGCGTCGTTTACGTGGGGGATTTTGTTAGGGGTATTCGCGTAGATTTTGCGCGTTTTTA

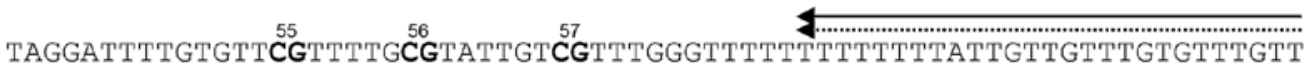

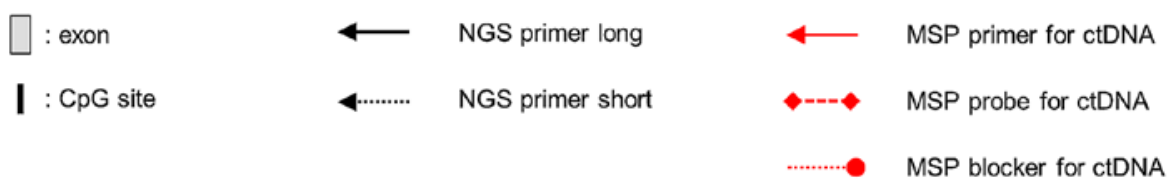

Figure 1. Primer design for DNA methylation analysis of SEPT9_v2 by NGS and for detection of methylated SEPT9_v2 ctDNA by real-time PCR. Two NGS primer sets were designed for methylation analysis of SEPT9_v2; 'NGS primer long' for DNA from cell lines and frozen tissues, and 'NGS primer short' for DNA from FFPE tissues. Methylated SEPT9_v2 ctDNA in plasma was detected by real-time PCR using the indicated primers, probes and blocker. The blocker has a $\mathrm{C} 3$ spacer in the 3 '-end to prevent extension.

Variation \%

Number of Reads (blue line)

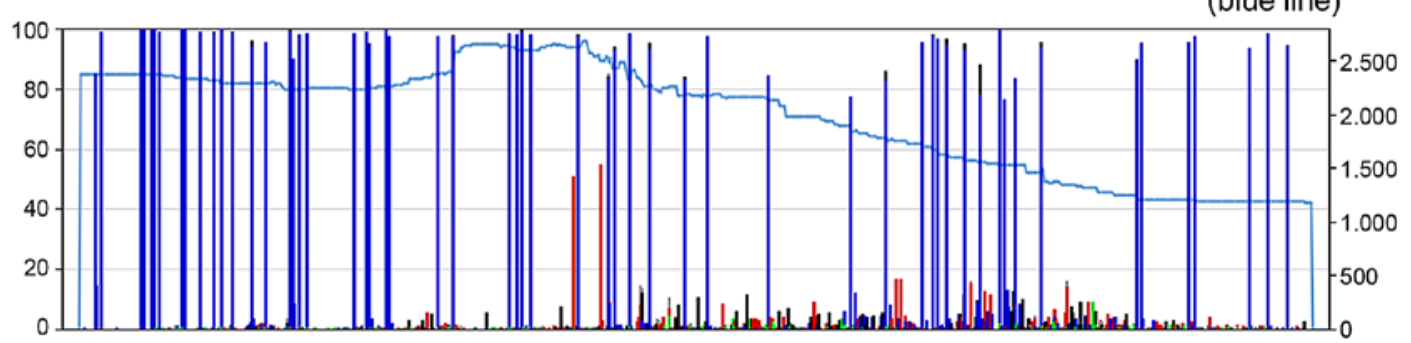

Bisulfite-reference sequence position

$\mathrm{A} \backslash \mathrm{C} \backslash \mathrm{G} \| \mathrm{T}$

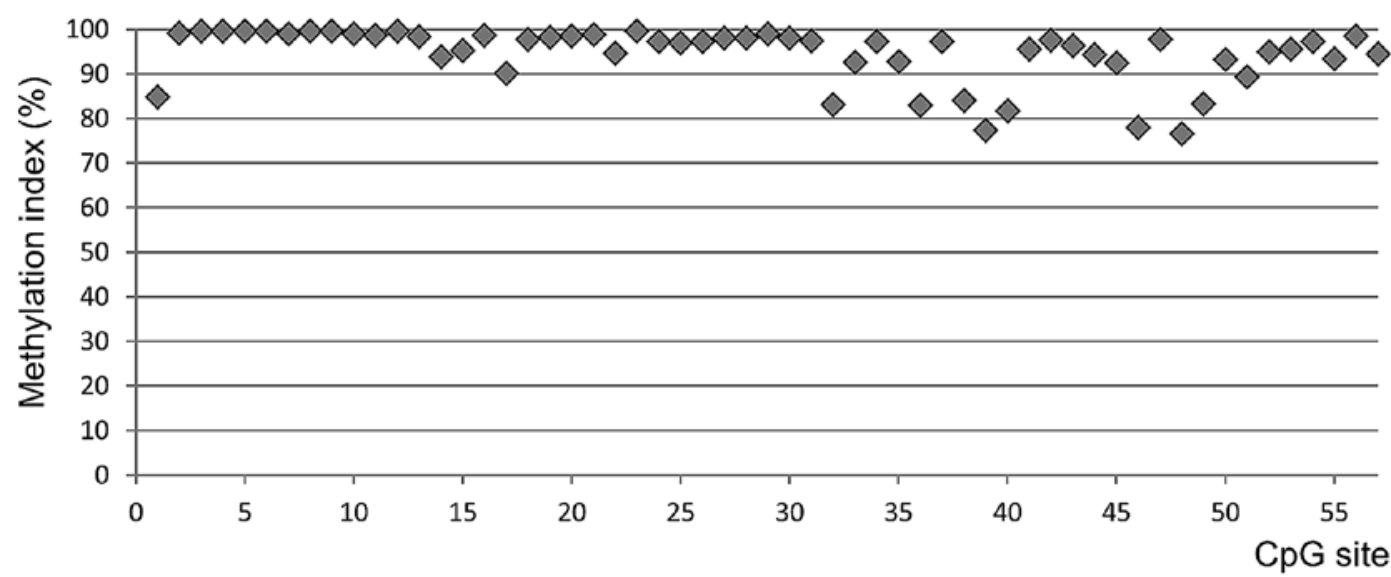

Figure 2. A representative result of SEPT9_v2 methylation analysis with NGS. The methylation status of 57 CpG sites was analyzed by means of NGS using NGS primer long. The MI of each CpG site was shown by blue bars (cytosine) (upper panel) and diamond symbols (lower panel). 

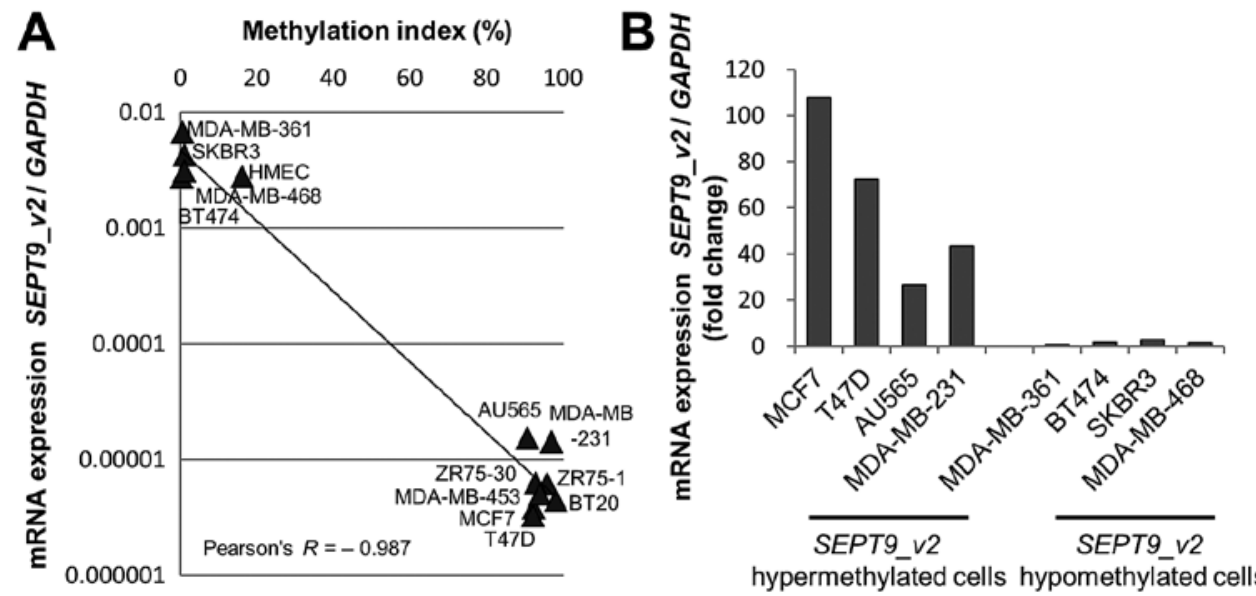

hypermethylated cells hypomethylated cells

Figure 3. SEPT9_v2 MI and mRNA expression in 13 breast cancer cell lines. (A) Correlation between the SEPT9_v2 MI and mRNA expression. The MI of SEPT9_v2 of 12 breast cancer cell lines and one normal breast epithelial cell line (HMEC) were determined by the NGS-based methylation assay and the correlation between the SEPT9_v2 MI and mRNA expression is shown. (B) SEPT9_v2 mRNA expression was evaluated before and after 5-aza-2'-deoxycytidine treatment in eight breast cancer cell lines and the fold-changes in SEPT9_v2 mRNA expression after 5-aza-2'-deoxycytidine treatment are represented.
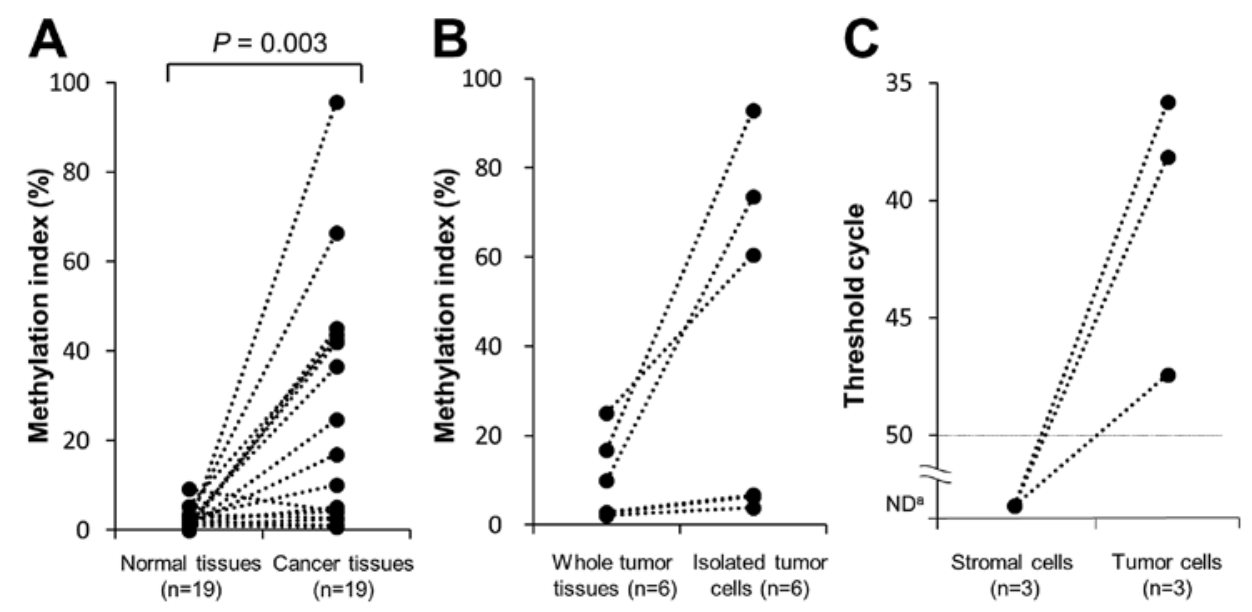

Figure 4. Methylation status of SEPT9_v2 in breast cancer and normal breast tissues. (A) The SEPT9_v2 MI was compared between 19 paired normal and cancerous breast tissues. (B) The SEPT9_v2 MI was assessed using isolated tumor cells by the MACS method and compared with non-isolated whole breast cancer tissues. (C) The SEPT9_v2 methylation level was assessed with MSP and compared between the epithelial cells and stromal cells separately collected by LCM from primary breast cancer tissues. ${ }^{\text {a }}$, not detectable.

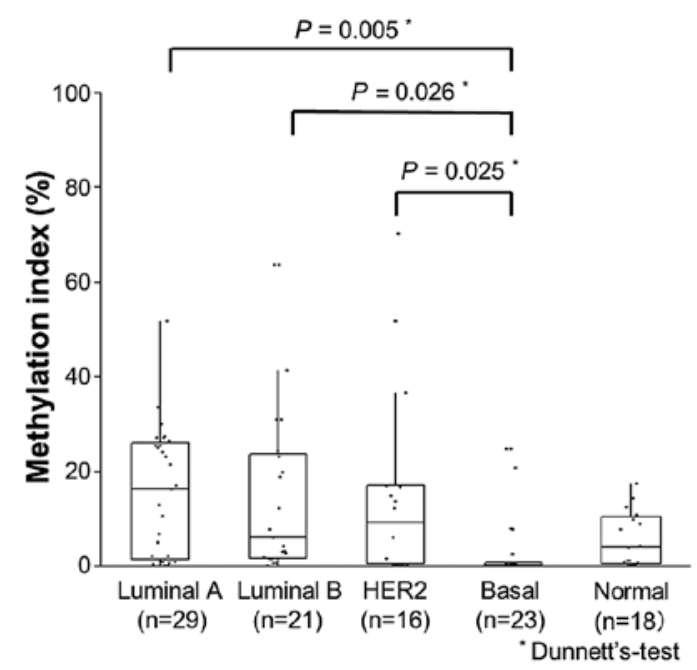

Figure 5. MI of SEPT9_v2 in 107 breast cancer tumors. Breast cancer tumors (107) were classified into the five intrinsic subtypes by PAM50 (luminal A, luminal B, HER2, basal-like, normal breast-like) and the MI of SEPT9_v2 was compared according to the intrinsic subtypes. "Dunnett's test. with hormone receptor positivity, low histological grade and non-pCR (Table II). The MI was significantly lower in basal type tumors $(3.0 \%)$ than in luminal $\mathrm{A}(\mathrm{P}=0.005)$, luminal $\mathrm{B}$ $(\mathrm{P}=0.026)$ or HER2 type $(\mathrm{P}=0.025)$ cancers (Fig. 5).

To determine whether methylation was related to gene expression, we performed ISH of SEPT9_v2 and GAPDH mRNA in the SEPT9_v2 hypermethylated $(\mathrm{n}=10)$ and hypomethylated tumors $(\mathrm{n}=10)$. GAPDH mRNA was expressed in both the SEPT9_v2 hypermethylated and hypomethylated tumors (Fig. 6B). In contrast, ISH signals of SEPT9_v2 mRNA in tumor cells were negative or barely detectable in all 10 hypermethylated tumors, but were clearly detectable in eight of 10 hypomethylated tumors (Fig. 6A).

Relationship between SEPT9_v2 methylation and the response to NAC. Clinicopathological parameters were evaluated by univariate analysis for their association with pCR (Table III). Age, Ki67, ER, PR, HER2 and SEPT9_v2 methylation status were significantly associated with pCR. 
A SEPT9_v2 hypomethylated tumors

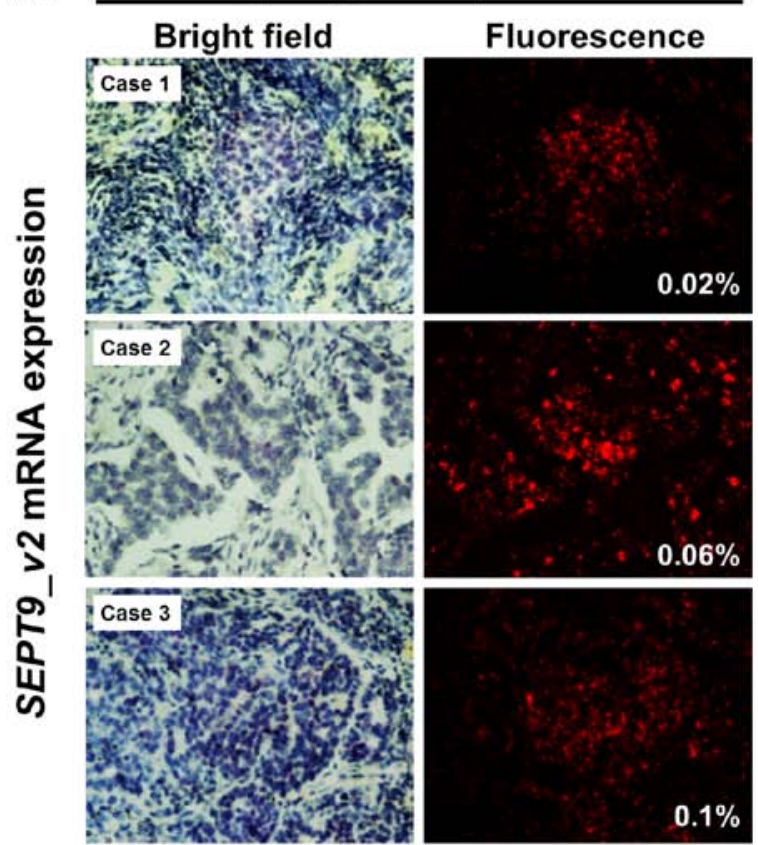

B

\section{Bright field}
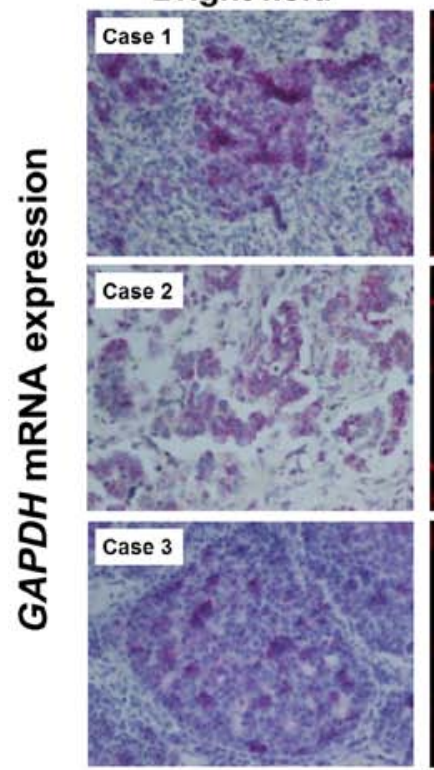

$\overline{100 \mu \mathrm{m}}$

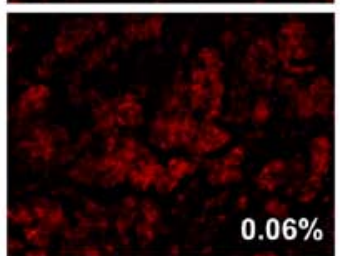

SEPT9_v2 hypermethylated tumors

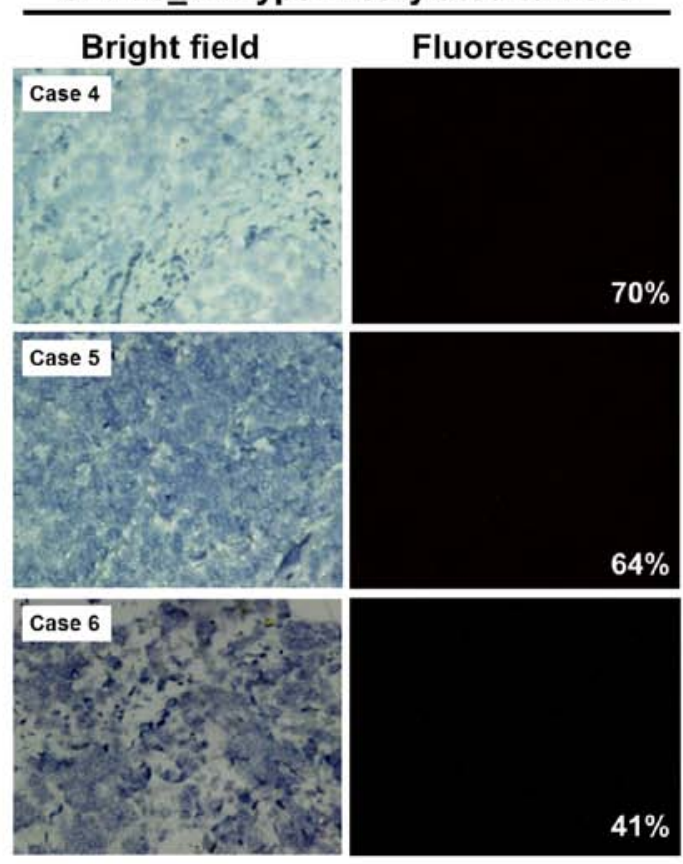

SEPT9_v2 hypermethylated tumors

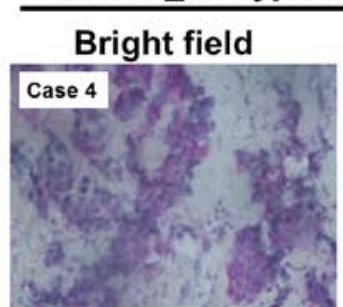

Fluorescence
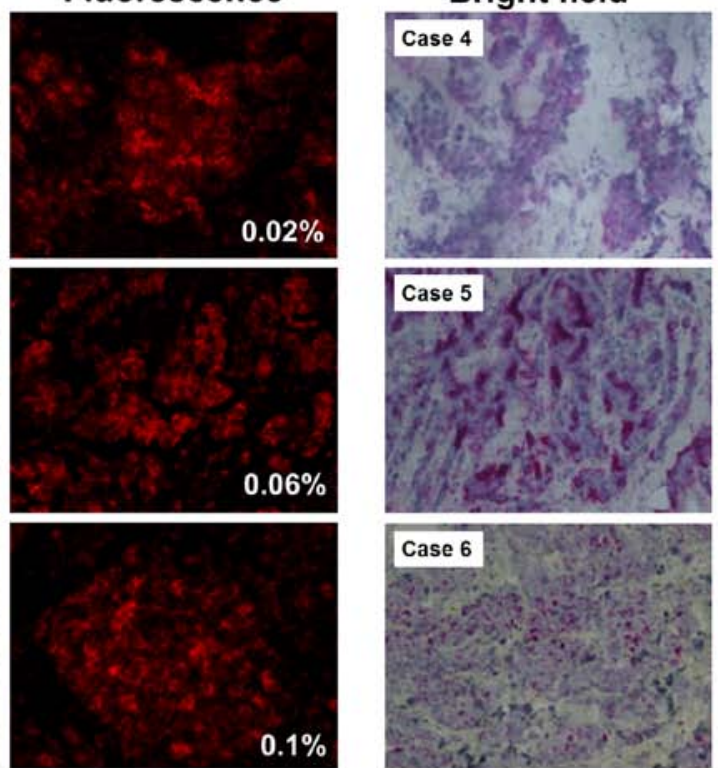

$\times 400$
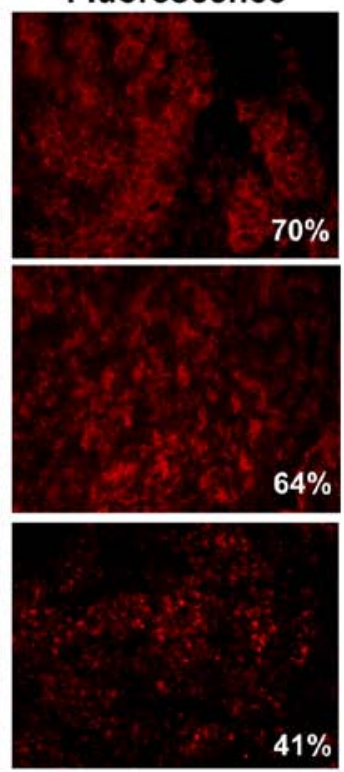

$\%$; methylation index

Figure 6. Representative ISH results of SEPT9_v2 and GAPDH mRNA expression in breast cancer tissues. (A) ISH for SEPT9_v2 mRNA and (B) GAPDH mRNA was conducted in SEPT9_v2 hypomethylated or hypermethylated breast cancer tissues. Microscopic images were obtained by light and fluorescence microscopy. The MI of SEPT9_v2 in each tumor is expressed as a percentage.

Multivariate analysis showed that ER, but not SEPT9_v2 methylation, was a significant and independent predictor for pCR. The SEPT9_v2 methylation status of breast tumors before and after NAC was also investigated in 20 patients with residual tumors (non-pCR) after NAC including 10 patients with SEPT9_v2 hypermethylated tumors and 10 patients with hypomethylated tumors before NAC. The methylation status of the residual tumors was completely the same as that of the tumors before NAC, i.e., all of 10 SEPT9_v2 hypermethylated tumors before NAC showed hypermethylation in the residual tumors after NAC and all of 10 SEPT9_v2 hypomethylated tumors before NAC showed hypomethylation in the residual tumors after NAC (data not shown).

To further investigate the effect of SEPT9_v2 on chemosensitivity, we carried out a knockdown assay with SEPT9_v2 siRNA for MDA-MB-468 cells, in which SEPT9_v2 is highly expressed and sensitive to both paclitaxel and epirubicin. SEPT9_v2 siRNA specifically decreased the expression of SEPT9_v2 in MDA-MB-468 cells (Fig. 7A) and the $\mathrm{IC}_{50}$ value 
Table III. Univariate and multivariate analysis of clinicopathological parameters for pCR.

\begin{tabular}{|c|c|c|c|c|c|c|}
\hline \multirow[b]{2}{*}{ Characteristics } & \multicolumn{3}{|c|}{ Univariate analysis } & \multicolumn{3}{|c|}{ Multivariate analysis } \\
\hline & Odds ratio & $95 \% \mathrm{CI}$ & P-value & Odds ratio & $95 \% \mathrm{CI}$ & P-value \\
\hline $\begin{array}{l}\text { Age (years) } \\
(\geq 50 \text { vs. }<50)\end{array}$ & 3.14 & $1.32-7.98$ & 0.009 & 2.74 & $0.98-8.10$ & 0.054 \\
\hline $\begin{array}{l}\text { T stage } \\
(\mathrm{T} 1,2 \text { vs. } \mathrm{T} 3,4)\end{array}$ & 1.80 & $0.64-5.90$ & 0.274 & & & \\
\hline $\begin{array}{l}\text { Lymph node status } \\
\text { (positive vs. negative) }\end{array}$ & 1.68 & $0.66-4.68$ & 0.286 & & & \\
\hline $\begin{array}{l}\text { Ki67 } \\
\text { (positive vs. negative) }\end{array}$ & 3.04 & $1.25-8.02$ & 0.013 & 1.49 & $0.48-4.68$ & 0.489 \\
\hline $\begin{array}{l}\text { ER } \\
\text { (negative vs. positive) }\end{array}$ & 10.5 & $4.16-29.0$ & $<0.001$ & 7.97 & $2.15-39.40$ & 0.001 \\
\hline $\begin{array}{l}\text { PR } \\
\text { (negative vs. positive) }\end{array}$ & 5.60 & $2.09-17.9$ & $<0.001$ & 0.73 & $0.12-3.58$ & 0.697 \\
\hline $\begin{array}{l}\text { HER2 } \\
\text { (positive vs. negative) }\end{array}$ & 2.47 & $1.02-5.99$ & 0.044 & 1.74 & $0.62-4.88$ & 0.291 \\
\hline $\begin{array}{l}\text { SEPT9_v2 methylation } \\
(<10 \text { vs. } \geq 10 \%)\end{array}$ & 2.99 & $1.20-8.25$ & 0.018 & 1.61 & $0.48-5.48$ & 0.440 \\
\hline
\end{tabular}

CI, confidence interval; ER, estrogen receptor; PR, progesterone receptor.
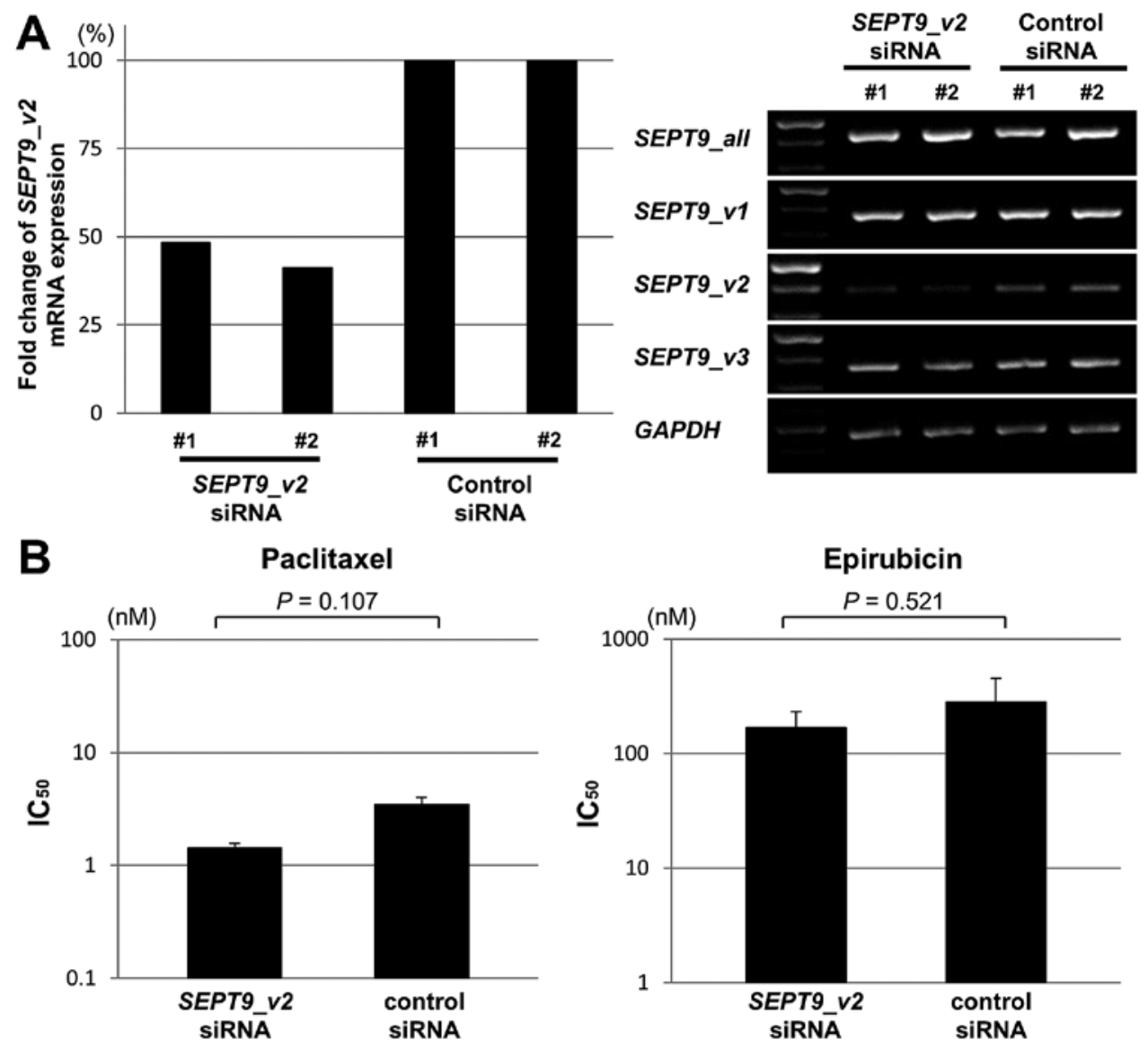

Figure 7. The knockdown effect of SEPT9_v2 mRNA on chemosensitivity of breast cancer cells. (A) The knockdown effect of SEPT9_v2 siRNA in MDA-MB-468 cells were assessed with real-time PCR (left) and RT-PCR (right). SEPT9_v1 and SEPT9_v3 were evaluated with RT-PCR to ascertain the specificity of SEPT9_v2 siRNA (right). (B) The $\mathrm{IC}_{50}$ value of paclitaxel and epirubicin was compared between SEPT9_v2 siRNA-treated MDA-MB-468 and the control cells. 


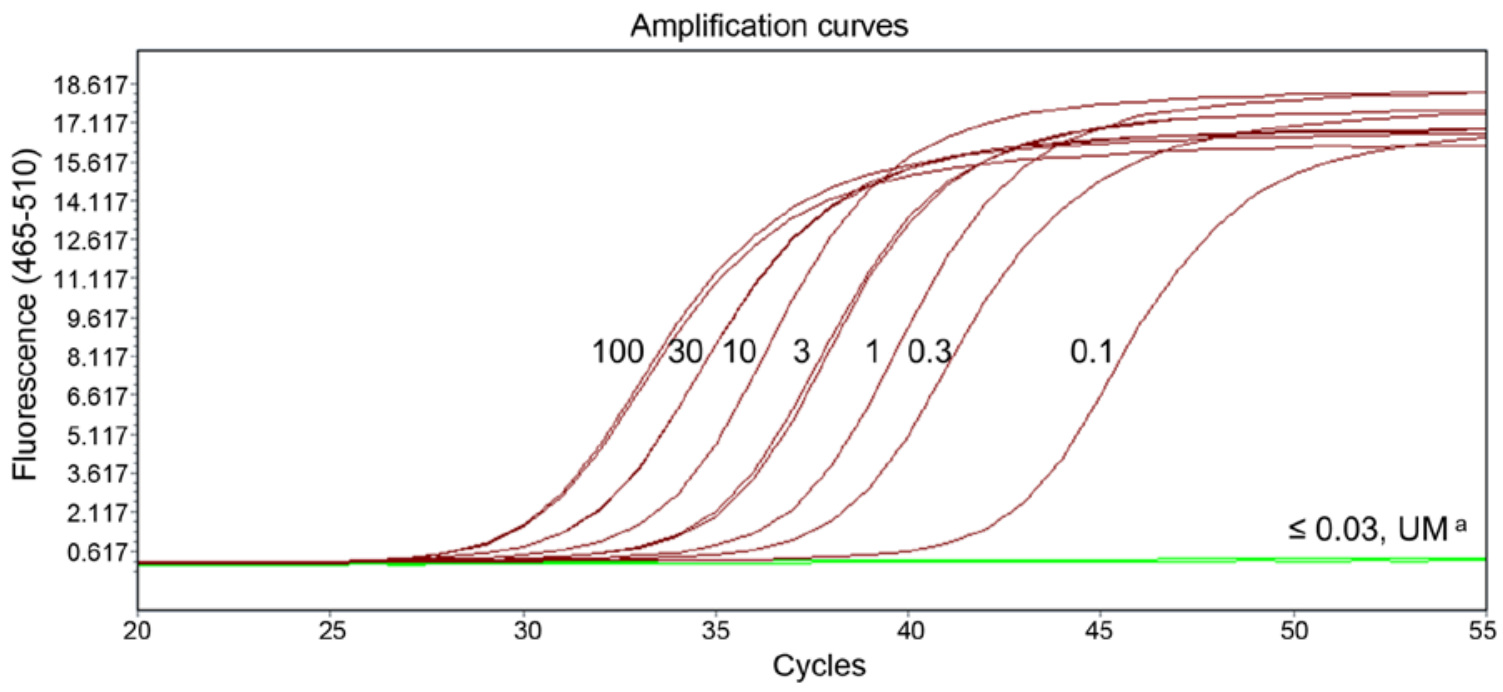

Figure 8. The amplification curves of a real-time PCR assay for SEPT9_v2 promoter methylation. The amplification curves of the eight standards were obtained by diluting the methylated human control DNA to $100,30,10,3,1,0.3,0.1$ and $0.03 \mathrm{ng} / \mathrm{well}$. ${ }^{\text {a }}$, Unmethylated DNA.

Table IV. Detection sensitivity of methylated SEPT9_v2 in plasma of primary and metastatic breast cancer patients (study III).

\begin{tabular}{|c|c|c|c|}
\hline & \multirow[b]{2}{*}{ Total } & \multicolumn{2}{|c|}{$\begin{array}{c}\text { Methylated SEPT9_v2 } \\
\text { in plasma }\end{array}$} \\
\hline & & $\begin{array}{l}\text { Positive } \\
\text { No. }(\%)\end{array}$ & $\begin{array}{l}\text { Negative } \\
\text { No. }(\%)\end{array}$ \\
\hline Healthy control & 51 & $0(0)$ & $51(100)$ \\
\hline PBC patients & 82 & $9(11)$ & $73(89)$ \\
\hline MBC patients & 50 & $26(52)$ & $24(48)$ \\
\hline $\mathrm{PBC}+\mathrm{MBC}$ patients $^{\mathrm{a}}$ with & 74 & & \\
\hline $\begin{array}{l}\text { SEPT9_v2 } \\
\text { hypermethylated tumors }\end{array}$ & 50 & $17(34)$ & $33(66)^{\mathrm{b}}$ \\
\hline $\begin{array}{l}\text { SEPT9_v2 } \\
\text { hypomethylated tumors }\end{array}$ & 24 & $2(8)$ & $22(92)$ \\
\hline
\end{tabular}

PBC; primary breast cancer; $\mathrm{MBC}$, metastatic breast cancer; ${ }^{\text {aprimary }}$ tumor tissues were available from 49 PBC patients and $25 \mathrm{MBC}$ patients for $S E P T 9 \_v 2$ methylation assay; ${ }^{\mathrm{P}} \mathrm{P}<0.05$; $\mathrm{PBC}$, primary breast cancer; $\mathrm{MBC}$, metastatic breast cancer.

for both paclitaxel and epirubicin was not significantly different between SEPT9_v2 siRNA-treated and control cells (Fig. 7B).

Detection of methylated SEPT9_v2 ctDNA in breast cancer patients. The presence of methylated SEPT9_v2 ctDNA was assessed in plasma from $82 \mathrm{PBC}$ and $50 \mathrm{MBC}$ patients, and 51 healthy controls (study III). An amplification curve of the eight standards was obtained by diluting the methylated human control DNA to $100,30,10,3,1,0.3,0.1$ and $0.03 \mathrm{ng} /$ well (Fig. 8). The limit of detection for methylated SEPT9_v2 DNA was $0.1 \mathrm{ng} /$ well. Methylated SEPT9_v2 ctDNA was detected in $11 \%(9 / 82)$ of PBC patients, and 52\% (26/50) of MBC patients, but not in any of the healthy controls (Table IV). In addition, the methylation status of SEPT9_v2 was investigated in the primary tumors available from $\mathrm{PBC}$ patients $(\mathrm{n}=49)$ and $\mathrm{MBC}$ patients $(\mathrm{n}=25)$. SEPT9_v2 hypermethylation in the primary tumors was found in 67\% (33/49) of PBC patients and 68\% $(17 / 25)$ of MBC patients. Methylated SEPT9_v2 ctDNA was significantly $(\mathrm{P}<0.05)$ more frequently observed in the $\mathrm{PBC}$ and MBC patients with SEPT9_v2 hypermethylated tumors [34\% (17/50)] than those with SEPT9_v2 hypomethylated tumors $[8 \%(2 / 24)]$ (Table IV), indicating a positive correlation of SEPT9_v2 hypermethylation in primary tumors with the presence of SEPT9_v2 ctDNA. However, in order to confirm that SEPT9_v2 methylated ctDNA actually originated from tumor cells, tumor cells and stromal cells were separately collected by means of LCM and subjected to the methylation assay in three patients positive for SEPT9_v2 ctDNA. In all three patients, SEPT9_v2 methylation was detectable only in tumor cells but not in the stromal cells (Fig. 4C).

\section{Discussion}

In the present study, SEPT9_v2 hypermethylation was observed in $8(67 \%)$ of the 12 breast cancer cell lines and $53 \%$ of breast tumor tissues examined (study I), but not in a normal human mammary epithelial cell line or normal breast tissues. The lower MI in tumor tissues compared to breast cancer cell lines may have resulted from the contamination of tumor tissue by normal stromal or inflammatory cells, since the tumor cells isolated by the MACS method showed higher MIs than the tumor tissue from which they were derived and since SEPT9_v2 methylation was observed in tumor cells but not in stromal cells separately obtained by LCM. These results clearly indicate that tumor cells actually harbor methylated SEPT9_v2.

We found that the expression of SEPT9_v2 mRNA was inversely correlated with the SEPT9_v2 MI in breast cancer cell lines, and that treatment of SEPT9_v2 hypermethylated breast cancer cell lines with a demethylating reagent resulted in the reactivation of SEPT9_v2 mRNA expression. These results 
clearly demonstrate that SEPT9_v2 expression is epigenetically regulated by promoter methylation in breast cancer cell lines, consistent with the studies on colorectal cancers (32). In addition, we confirmed such epigenetic regulation in breast tumor tissue using ISH to demonstrate that SEPT9_v2 mRNA expression was silenced in SEPT9_v2 hypermethylated tumors.

The SEPT9_v2 MI was significantly lower in basal type tumors than in other intrinsic tumor subtypes. This is consistent with the study that basal type tumors are globally hypomethylated as compared with other subtypes (33). Although SEPT9_v2 hypermethylation was significantly associated with non-pCR, this does not necessarily mean that such hypermethylation plays a significant role in chemotherapy resistance. Multivariate analysis failed to demonstrate that SEPT9_v2 hypermethylation was an independent predictor for non-pCR. In addition, we observed that knockdown of SEPT9_v2 mRNA by siRNA had no effect on chemosensitivity even though the potential involvement of SEPT9_V1 and SEPT9_V4 in chemoresistance has been reported (34-36). However, the methylation status of the residual tumors after NAC was completely the same as that of the tumors before NAC, indicating that chemotherapy did not affect the SEPT9_v2 methylation status. Thus, it is possible that SEPT9_v2 hypermethylation is indirectly associated with non-pCR via its strong association with the $\mathrm{ER}$, which is a well-established predictor for non-pCR (37-39). Taken together, SEPT9_v2 is unlikely to play a significant role in chemoresistance, and is not a clinically useful predictor for non-pCR.

Methylated SEPT9_v2 ctDNA appears to be one of the most successful markers for the early detection of colorectal cancer. Since a recent study showed that this ctDNA can be detected in lung cancer patients (40), its clinical utility for other types of cancers needs to be clarified. The present study revealed that methylated SEPT9_v2 ctDNA was detectable in $11 \%$ of $\mathrm{PBC}$ patients and $52 \%$ of MBC patients and that it was significantly more frequently observed in the $\mathrm{PBC} / \mathrm{MBC}$ patients with hypermethylated tumors than those with hypomethylated tumors. However, the sensitivity of this methylated ctDNA for PBC and MBC was lower than that for primary and metastatic colorectal cancer (45 and 77\%, respectively) (22). This lower sensitivity can be explained by the lower proportion of methylated SEPT9_v2 breast cancer [50\% (100/200), all tumors combined in the present study] compared to colorectal cancer (82\%) (41). Another potential explanation is the different methods of assay that were used. The methylated SEPT9_v2 ctDNA detection kit, known as Epi proColon ${ }^{\circledR} 2.0$ (Epigenomics AG, Berlin, Germany), can detect $14 \mathrm{pg} / \mathrm{ml}$ of this ctDNA. This high sensitivity is achieved by a triplicate assay using a greater volume of plasma $(3.5 \mathrm{ml})$. The present study was carried out by a single assay using less plasma $(2 \mathrm{ml})$ since our retrospective samples contained insufficient volumes.

In conclusion, although methylation of many other genes has been reported in breast cancer (3-9), methylation status of SEPT9_v2 and its correlation with mRNA expression has yet to be studied in human breast cancers. Then, we analyzed this issue, and were able to show that hypermethylation of SEPT9_v2 was seen in a high proportion of breast tumors and that its methylation was clearly correlated with the silencing of
SEPT9_v2 mRNA expression. However, we could show for the first time that SEPT9_v2 methylated ctDNA was detectable in a significant proportion of $\mathrm{PBC}$ and $\mathrm{MBC}$ patients, suggesting a possibility that $S E P T 9 \_v 2$ methylated ctDNA may serve as a novel tumor marker. Our present observation needs to be further investigated in a future study including a larger number of patients.

\section{Acknowledgements}

The present study was supported in part by Grants-in-Aid from the Knowledge Cluster Initiative of the Ministry of Education, Culture, Sports, Science and Technology of Japan.

\section{References}

1. Esteller M: Epigenetics in cancer. N Engl J Med 358: 1148-1159, 2008.

2. Rodríguez-Paredes M and Esteller M: Cancer epigenetics reaches mainstream oncology. Nat Med 17: 330-339, 2011.

3. Yamamoto N, Nakayama T, Kajita M, Miyake T, Iwamoto T, Kim SJ, Sakai A, Ishihara H, Tamaki Y and Noguchi S: Detection of aberrant promoter methylation of GSTP1, RASSF1A, and RAR $\beta 2$ in serum DNA of patients with breast cancer by a newly established one-step methylation-specific PCR assay. Breast Cancer Res Treat 132: 165-173, 2012.

4. Fujita N, Nakayama T, Yamamoto N, Kim SJ, Shimazu K, Shimomura A, Maruyama N, Morimoto K, Tamaki Y and Noguchi S: Methylated DNA and total DNA in serum detected by one-step methylation-specific PCR is predictive of poor prognosis for breast cancer patients. Oncology 83: 273-282, 2012.

5. Fujita N, Kagara N, Yamamoto N, Shimazu K, Shimomura A, Shimoda M, Maruyama N, Naoi Y, Morimoto K, Oda N, et al: Methylated DNA and high total DNA levels in the serum of patients with breast cancer following neoadjuvant chemotherapy are predictive of a poor prognosis. Oncol Lett 8: 397-403, 2014.

6. Hoque MO, Feng Q, Toure P, Dem A, Critchlow CW, Hawes SE, Wood T, Jeronimo C, Rosenbaum E, Stern J, et al: Detection of aberrant methylation of four genes in plasma DNA for the detection of breast cancer. J Clin Oncol 24: 4262-4269, 2006.

7. Avraham A, Uhlmann R, Shperber A, Birnbaum M, Sandbank J, Sella A, Sukumar S and Evron E: Serum DNA methylation for monitoring response to neoadjuvant chemotherapy in breast cancer patients. Int J Cancer 131: E1166-E1172, 2012.

8. Sharma G, Mirza S, Parshad R, Gupta SD and Ralhan R: DNA methylation of circulating DNA: A marker for monitoring efficacy of neoadjuvant chemotherapy in breast cancer patients. Tumour Biol 33: 1837-1843, 2012.

9. Fackler MJ, Lopez Bujanda Z, Umbricht C, Teo WW, Cho S, Zhang Z, Visvanathan K, Jeter S, Argani P, Wang C, et al: Novel methylated biomarkers and a robust assay to detect circulating tumor DNA in metastatic breast cancer. Cancer Res 74: 2160-2170, 2014

10. Arai T, Miyoshi Y, Kim SJ, Taguchi T, Tamaki Y and Noguchi S: Association of GSTP1 CpG islands hypermethylation with poor prognosis in human breast cancers. Breast Cancer Res Treat 100: 169-176, 2006

11. Miyake T, Nakayama T, Naoi Y, Yamamoto N, Otani Y, Kim SJ, Shimazu K, Shimomura A, Maruyama N, Tamaki Y, et al: GSTP1 expression predicts poor pathological complete response to neoadjuvant chemotherapy in ER-negative breast cancer. Cancer Sci 103: 913-920, 2012.

12. Mostowy S and Cossart P: Septins: The fourth component of the cytoskeleton. Nat Rev Mol Cell Biol 13: 183-194, 2012.

13. Robertson C, Church SW, Nagar HA, Price J, Hall PA and Russell SE: Properties of SEPT9 isoforms and the requirement for GTP binding. J Pathol 203: 519-527, 2004

14. Peterson EA and Petty EM: Conquering the complex world of human septins: Implications for health and disease. Clin Genet 77: 511-524, 2010.

15. Kalikin LM, Sims HL and Petty EM: Genomic and expression analyses of alternatively spliced transcripts of the $M L L$ septinlike fusion gene $(M S F)$ that map to a $17 \mathrm{q} 25$ region of loss in breast and ovarian tumors. Genomics 63: 165-172, 2000. 
16. Russell SE, McIlhatton MA, Burrows JF, Donaghy PG, Chanduloy S, Petty EM, Kalikin LM, Church SW, McIlroy S, Harkin DP, et al: Isolation and mapping of a human septin gene to a region on chromosome $17 \mathrm{q}$, commonly deleted in sporadic epithelial ovarian tumors. Cancer Res 60: 4729-4734, 2000.

17. Montagna C, Lyu MS, Hunter K, Lukes L, Lowther W, Reppert T, Hissong B, Weaver Z and Ried T: The Septin $9(M S F)$ gene is amplified and overexpressed in mouse mammary gland adenocarcinomas and human breast cancer cell lines. Cancer Res 63 2179-2187, 2003

18. Connolly D, Abdesselam I, Verdier-Pinard P and Montagna C: Septin roles in tumorigenesis. Biol Chem 392: 725-738, 2011.

19. Lofton-Day C, Model F, Devos T, Tetzner R, Distler J, Schuster M, Song X, Lesche R, Liebenberg V, Ebert M, et al: DNA methylation biomarkers for blood-based colorectal cancer screening. Clin Chem 54: 414-423, 2008

20. deVos T, Tetzner R, Model F, Weiss G, Schuster M, Distler J, Steiger KV, Grützmann R, Pilarsky C, Habermann JK, et al: Circulating methylated SEPT9 DNA in plasma is a biomarker for colorectal cancer. Clin Chem 55: 1337-1346, 2009.

21. Warren JD, Xiong W, Bunker AM, Vaughn CP, Furtado LV, Roberts WL, Fang JC, Samowitz WS and Heichman KA Septin 9 methylated DNA is a sensitive and specific blood test for colorectal cancer. BMC Med 9: 133, 2011

22. Church TR, Wandell M, Lofton-Day C, Mongin SJ, Burger M, Payne SR, Castaños-Vélez E, Blumenstein BA, Rösch T, Osborn N, et al; PRESEPT Clinical Study Steering Committee, Investigators and Study Team: Prospective evaluation of methylated SEPT9 in plasma for detection of asymptomatic colorectal cancer. Gut 63: 317-325, 2014.

23. Connolly D, Yang Z, Castaldi M, Simmons N, Oktay MH, Coniglio S, Fazzari MJ, Verdier-Pinard P and Montagna C: Septin 9 isoform expression, localization and epigenetic changes during human and mouse breast cancer progression. Breast Cancer Res 13: R76, 2011.

24. Naoi Y, Kishi K, Tanei T, Tsunashima R, Tominaga N, Baba Y, Kim SJ, Taguchi T, Tamaki Y and Noguchi S: Development of 95-gene classifier as a powerful predictor of recurrences in nodenegative and ER-positive breast cancer patients. Breast Cancer Res Treat 128: 633-641, 2011.

25. Parker JS, Mullins M, Cheang MC, Leung S, Voduc D, Vickery T, Davies S, Fauron C, He X, Hu Z, et al: Supervised risk predictor of breast cancer based on intrinsic subtypes. J Clin Oncol 27: $1160-1167,2009$

26. Mishima C, Kagara N, Tanei T, Naoi Y, Shimoda M, Shimomura A, Shimazu K, Kim SJ and Noguchi S: Mutational analysis of MED12 in fibroadenomas and phyllodes tumors of the breast by means of targeted next-generation sequencing. Breast Cancer Res Treat 152: 305-312, 2015.

27. Pfütze K, Benner A, Hoffmeister M, Jansen L, Yang R, Bläker H, Herpel E, Ulrich A, Ulrich CM, Chang-Claude J, et al: Methylation status at HYAL2 predicts overall and progression-free survival of colon cancer patients under 5-FU chemotherapy. Genomics 106 348-354, 2015

28. Lee ES, Issa JP, Roberts DB, Williams MD, Weber RS, Kies MS and El-Naggar AK: Quantitative promoter hypermethylation analysis of cancer-related genes in salivary gland carcinomas: Comparison with methylation-specific PCR technique and clinical significance. Clin Cancer Res 14: 2664-2672, 2008.
29. Nygren AO, Ameziane N, Duarte HM, Vijzelaar RN, Waisfisz Q Hess CJ, Schouten JP and Errami A: Methylation-specific mlPA (MS-MLPA): Simultaneous detection of CpG methylation and copy number changes of up to 40 sequences. Nucleic Acids Res 33: e128, 2005.

30. Toyota M, Kopecky KJ, Toyota MO, Jair KW, Willman CL and Issa JP: Methylation profiling in acute myeloid leukemia. Blood 97: 2823-2829, 2001.

31. Otani Y, Miyake T, Kagara N, Shimoda M, Naoi Y, Maruyama N, Shimomura A, Shimazu K, Kim SJ and Noguchi S: BRCAl promoter methylation of normal breast epithelial cells as a possible precursor for $B R C A 1$-methylated breast cancer. Cancer Sci 105: 1369-1376, 2014.

32. Tóth K, Galamb O, Spisák S, Wichmann B, Sipos F, Valcz G, Leiszter K, Molnár B and Tulassay Z: The influence of methylated septin 9 gene on RNA and protein level in colorectal cancer. Pathol Oncol Res 17: 503-509, 2011.

33. Network CGA; Cancer Genome Atlas Network: Comprehensive molecular portraits of human breast tumours. Nature 490: 61-70, 2012.

34. Amir S and Mabjeesh NJ: SEPT9_V1 protein expression is associated with human cancer cell resistance to microtubule-disrupting agents. Cancer Biol Ther 6: 1926-1931, 2007.

35. Froidevaux-Klipfel L, Poirier F, Boursier C, Crépin R, Poüs C, Baudin B and Baillet A: Modulation of septin and molecular motor recruitment in the microtubule environment of the Taxol-resistant human breast cancer cell line MDA-MB-231. Proteomics 11: 3877-3886, 2011.

36. Chacko AD, McDade SS, Chanduloy S, Church SW, Kennedy R, Price J, Hall PA and Russell SE: Expression of the SEPT9 i4 isoform confers resistance to microtubule-interacting drugs. Cell Oncol 35: 85-93, 2012

37. Carey LA, Dees EC, Sawyer L, Gatti L, Moore DT, Collichio F, Ollila DW, Sartor CI, Graham ml and Perou CM: The triple negative paradox: Primary tumor chemosensitivity of breast cancer subtypes. Clin Cancer Res 13: 2329-2334, 2007.

38. Rouzier R, Perou CM, Symmans WF, Ibrahim N, Cristofanilli M, Anderson K, Hess KR, Stec J, Ayers M, Wagner P, et al: Breast cancer molecular subtypes respond differently to preoperative chemotherapy. Clin Cancer Res 11: 5678-5685, 2005.

39. Ignatiadis $M$ and Sotiriou C: Luminal breast cancer: From biology to treatment. Nat Rev Clin Oncol 10: 494-506, 2013.

40. Powrózek T, Krawczyk P, Kucharczyk T and Milanowski J: Septin 9 promoter region methylation in free circulating DNA-potential role in noninvasive diagnosis of lung cancer: Preliminary report. Med Oncol 31: 917, 2014.

41. Ahmed D, Danielsen SA, Aagesen TH, Bretthauer M, Thiis-Evensen E, Hoff G, Rognum TO, Nesbakken A, Lothe RA and Lind GE: A tissue-based comparative effectiveness analysis of biomarkers for early detection of colorectal tumors. Clin Transl Gastroenterol 3: e27, 2012. 